Book Reviews

\title{
FATHERS AND MOTHERS
}

Paternal Deprivation. Henry B. Biller. Lexington, Massachusetts, Lexington Books, D.C. Heath, 1974. xi 226 pp.

The Father: His Role in Child Development. David B. Lynn. Monterey, California, Brooks/Cole Publishing Company, 1974. xiii + 333 pp.

Until the past decade, from the point of view of psychological research, the father was a neglected family member. Mother-child relations were studied, mother love extolled, and matemal separation from the child decried. However, the father remained a theoretically important but relatively unstudied family member. Even when a trickle of research on fathers began to appear in the 1940 s and 1950s, it frequently was focused on the effects of father absence rather than on the role of an available father on family interaction and the development of children. In addition, in these early investigations the father was rarely directly studied; rather mothers' or children's reports of patemal behavior were relied on.

In the past 10 years, studies of fathers have burgeoned. Information on the impact of fathers on family functioning and on the social, emotional, and cognitive development of the child has been accumulating at an accelerating rate. It is therefore timely that two books on fathers have appeared by two of the men who have contributed most to our understanding of fathers and fathering. Although David Lynn's book is called The Father: His Role in Child Development and Henry Biller's is called Patemal Deprivation, much of the same research is reviewed in both volumes. In addition each of the authors within the past few years has published another book dealing with some of the same material. In 1971 Biller authored Father, Child, and Sex Role (Lexington Books, D.C. Heath), and in 1969 Lynn wrote Parental and Sex Role Identification (McCutchan Publishing Corporation). Although there is considerable overlap between the earlier and later books, the interested reader should not be dissuaded from reading the new volumes. New research and fresh perspectives have been added in the current ones.

(c) 1976 Plenum Publishing Corporation, 227 West $17 t$ h street, New York, N.Y. 10011 . No part of this publication may be reproduced, stored in a retrieval system, or transmitted, in any form or by any means, electronic, mechanical, photocopying, microfilming, recording. or otherwise, without written permission of the publisher. 
David Lynn has made some of the most important theoretical contributions to our understanding of fathers. Henry Biller has extended Lynn's theory of sex-role typing and has been perhaps the most prolific researcher on the topic of fathers, particularly on father absence. Lynn's greater preoccupation with theory and Biller's research expertise are reflected in their books.

What distinguishes Lynn's new book is his presentation of the role of the father from a historical, crosscultural, and cross-species perspective. The book is divided into two parts. In Part One: Fathers and Cultures, Lynn deals with the American fathers' historical heritage, reviewing the historical antecedents of the role of fathers not only in this country but in ancient, Hebrew, and Roman cultures and also early Anglo-Saxon and French times. He then goes on to analyze changes in the role of contemporary American fathers and the pressures on the family, particularly on fathers, that are leading to these transitions. A perceptive analysis of cultural experiments in restructuring the family such as those in Sweden, the Soviet Union, the kibbutzim, and the American communes is also presented. It is a delightful, scholarly, stimulating presentation interspersed with literary passages, verse, and doggerel on the father.

The second section of Lynn's book, entitled The Father-Child Relationship, covers many of the same topics reviewed in Biller's book. Both authors deal with theories of the father's role, the father's child-rearing practices, the fathermother relationship, and the impact of fathers and father absence on sex-role behavior, social, emotional, and cognitive development, and the development of deviant behavior in children.

Don't be misled by the title of Biller's book. Although it purports to deal with paternal deprivation it contains an unusually comprehensive review of the research literature on fathers both absent and present. What distinguishes this new book of Biller's from his earlier book on fathers is "a concentration on various forms of paternal deprivation, a strong focus on the father-infant and father-mother relationships, a detailed analysis of the influence of fathering on cognitive functioning and school adjustment, and much more emphasis on the ways in which fathering can contribute to the development of personal sexual and social problems" (Biller, 1974, xi).

Biller's research experience is apparent in his careful examination of methodological problems in studies of father absence and limitations in the interpretation of these studies because of these methodological deficits. There are only a small number of recent studies which examine the effects of such critical variables as social class, reason for absence of the father (death, divorce, desertion), time and length of father absence, and sex of the child in investigating the effects of paternal deprivation on child development. In spite of these limitations, the author presents a convincing body of knowledge demonstrating possible deleterious effects of father absence on the intellectual, personality, and social development of children. He also takes care to point out that the 
effects of a conflictual home atmosphere or of an intact home in which the father is unavailable or inadequate may be as bad as or worse than that of a single-parent family.

Currently about 1 in 10 children are children reared in single-parent homes, and in black urban areas this figure may rise to over $50 \%$. The number of single-parent families is likely to increase in view of the rising divorce rate, experiments in new family forms, and the acceptance in most states of singleparent adoptions. It is distressing to find on reading such a comprehensive review of the literature that so little is known about functioning and coping in oneparent families. There is little research that has focused on the variations in family functioning and experiences that must mediate any differences found between children from intact and father-absent homes. It is apparent from Biller's review that studies of the different coping mechanisms and adjustment of mothers in single-parent families that are associated with positive or deviant development in children are critically needed.

It seems ungracious to carp at the appearance of two such fine books. However one gets the uneasy feeling that the pendulum which once was fixed in the direction of mothers may be swinging too far in the opposite direction toward fathers. There is a tendency to minimize the importance of one parent in focusing on the other. Since fathers have come into their own, what now seems to be needed is a more sophisticated analysis of the entire family system rather than single family members, in view of our rapidly accumulating research findings.

These two books combine a richness of experience, a familiarity with the literature, and a clarity of conceptualization that make a greatly needed contribution to our understanding of fathers. They fill a large gap in the current literature.

E. Mavis Hetherington University of Virginia

The Future of Motherhood. Jessie Bernard. New York, Baltimore, Penguin Books Inc. 1974, 426 pp. $\$ 2.95$

Women, Wives, Mothers. Jessie Bernard. Chicago, Aldine Publishing Company, $1975,286 \mathrm{pp}$.

These two books by Jessie Bernard are exciting and useful additions to the growing shelf of books on the special socialization and problems of girls and women in our society.

Dr. Bemard has given us new conceptual frameworks to use in thinking about the present status of women and has used empirical and innovative ideas from around the world to support and develop her various chapters. The works are extensively referenced and are suitable for use as texts, but throughout both 
books the author's buoyant personality enlivens the reading, recommending them also for professional and lay readers. The footnotes in Women, Wives, Mothers, conveniently placed on the pages where they are appropriate, are especially interesting for the glimpse they give of Dr. Bernard's own personal stance.

Dr. Bernard is a family sociologist with a long history of effective scholarship. Of late years her interests have tumed more and more to the status of women, most recently evidenced in her book, The Future of Marriage. In all these books, she is tackling the important social controversies of our times with wit and wisdom.

In the Future of Motherhood, the earlier of these two books, in eight parts and 18 chapters Dr. Bernard takes an historical, present, and finally futuristic view of motherhood. In Part I she discusses motherhood as Institution and points out that our model of motherhood was set in the Victorian era, and that we have forgotten that mothers are also human beings. In Part II she discusses "The First Imperative" to bear children and discusses the present socialization forces which make motherhood the only acceptable role for a woman. She presents interesting evidence that women who desire children and those who do not are not different in personality. Since she shows that the desired number of children varies at different times in our history, it is clear that there are fashions in this function as well as in so many others in our lives. In Part III, "The Second Imperative" to raise the children, she shows how the script for motherhood has changed over the centuries. At the present time the amount of "motherhood per child" is the most it has ever been because of smaller families and because childhood has been prolonged by the longer dependency of children today. The intensity and lack of clarity of the behaviors which will produce an adequate and constructive citizen are not clear, and we find a multiplicity of scripts and much psychological anguish on the part of the mothers.

Part IV, "Role Severance and Attrition," is concerned with women and their work lives. She discusses the fact that women have always worked but that most of that work was nonmonetized. Efforts have been extended toward making it simpler for women to carry their two roles if they went out of the home, but only now are women asking the question, "why only women's two roles?"

In Part V, which she calls "Gestating the Future." she describes how today's career mothers and working mothers are working out the roles and procedures which will be more common in the future. For many families this is bringing great changes to fathers. More and more men and women are drawing up contracts with each other to define the contribution each will make to the care of children they will produce. Dr. Bernard reports with great sympathy the plight of the new minority of mothers who stay at home and who now feel beleaguered as never before by those who have gone to work. The rear-guard action these women are fighting with the Equal Rights Amendment is described as their 
attempt to protect the privileges they believed were theirs. With the terrible cost in alcoholism and depression, these women are thought of as the "victims" of their socialization by Dr. Bernard.

Part VI deals with the "Technologies, Politics and Economics of Motherhood." Here we learn some interesting new ideas about technology and learn that the technologies of "carriages, carpets and cans" have served to isolate the mother from the child. She presents some new medical and socially innovative ideas of how technology can serve at this time to improve the lot of the mother. She tells us of the new discipline of "genetics" which is to examine the moral and ethical aspects of genetic and reproductive decisions which are made necessary by the biological technology. She points out that our governmental policy toward motherhood has been ambiguous - but probably pronatalist in the overall reckoning. Childbearing and child-rearing have political overtones that are only now being understood. For example, when society has the choice of having ADC women take the mother-role or the worker-role so as to be able to support themselves and their children, they are expected to take the worker-role. As this becomes a political issue, it also becomes an economic issue: who will pay for children? She points out that the earnings of married women contributed to the educational and schooling expenses of their children may have been the largest source of human capital investment in this country, and thus women's paid work has economic impact. In another way, when women commit themselves to children too heavily in their younger years and then experience the "empty nest" syndrome, this deferred cost to society must also be considered as an economic as well as social factor.

Part VII is concemed with the future of motherhood in experimental com. munities, or as we are revolutionizing our present arrangements through reformation. One chapter is a comprehensive and useful discussion of child-rearing in communes.

In this section she has brought together all sorts of suggested schemes to make our lives more flexible and foster our own self-determination. The "generalized drawing rights" plan she describes is at last an overall way to look at the life-span needs of both men and women as workers. and persons needing ad. vanced training or rejuvenation, or a time out for parenting.

The final Part VIII brings the conclusion that what is needed is "a balance within each sex rather than a balance between them." Motherhood is too important to leave just to women.

The second volume, Women, Wives, Mothers, is a collection of essays or chapters and includes the material from the first book on the ages and stages of motherhood.

For the journal Sex Roles, one of the most interesting chapters is that on sex-role transcendence, which is suggested by Heffner and Nordin as a more appropriate term than androgyny. It still remains an experimental question as to 
how people can reach the stage of transcendence and whether or not they must go through a previous stage of sex-role specialization before achieving transcendence.

In a fascinating chapter on Adolescence and Socialization for Motherhood, Dr. Bernard introduces her concept of tipping points at which times new shifts are evidenced in social or demographic trends. She discusses trends in the birth rate which have contributed to the pressure on young women to get married early and trends in the marriage rate which may reflect the fact that girls today are being socialized for labor force participation at the same time they are coming to think that marriage is no longer necessary to legalize sexual relationships. She discusses the tipping points in schooling and virginity. This chapter particularly would be useful for all those now involved with teenagers as parents and teachers. The eight vignetres of tenagers could be useful as discussion starters.

In later chapters she discusses the tipping-point concept in terms of attitudes. These are times at which an idea which has been held by the minority becomes a majority opinion. During the time of tipping the norms are not clear, leading to loosening of standards. When the previous majority becomes the minority they develop defensive feelings and organize to protect their status. The "Right-to-Life" movement is just such a response to the new majority attitude toward abortion. Many important values have passed through the tipping points during the 1970 s, and these are given fascinating treatment.

Some of the most interesting material in the book is that concerning the "Bitter fruits of extreme sex-role specialization" in which she brings together research showing the negative effect on both men and women of single-minded participation in their stereotyped roles of provider or mother.

Women, Wives, Mothers, is the more inclusive book, so if you plan to use only one this is probably the one to get. However, the Future of Motherhood greatly extends the coverage in the other book, especially in the policy sections. Both are highly recommended for the fresh insights and directions they provide.

Margaret Feldman Ithaca College

\section{POLITICAL AND ECONOMIC STRUCTURES}

Does Socialism Liberate Women? Hilda Scott. Boston, Beacon Press, 1974, 240 pp. $\$ 7.95$

Capitalism and its attendant system of private property were viewed by Marx and Engels as the root cause of the subjugation of women. Socialism would mean freedom and equality for both sexes. In this historical analysis of post-World War 
II Czechosiovakia, Hilda Scott questions whether socialism has indeed liberated women.

The analysis begins with an examination of the position of women in socialist thought. Marx and Engels held that the original stage of social organization, primitive communism, was matriarchal. Only after inherited private property was introduced did woman's place become secondary, since her most important function then became the production of heirs to whom the family's (father's) property could be passed. In The Origin of the Family, Private Property and the State (1884), Engels sets down this theory which he and Marx had developed. It was important for Marx and Engels to have scientific evidence that male domination was not generic to the human species, for if it had once not existed, then social conditions that would not support it could be recreated. They drew support for their ideas from the research of the American anthropologist, Lewis H. Morgan. Morgan's theory was that familial organization was a function of members' skills relating to the production of the means of subsistence. He argued that man's initial inability to produce more than he could consume made lineage considerations unimportant and that the earliest type of family organization was therefore group marriage. Since group marriage precludes the identity of fathers, the meager status and possessions of the group had to be passed through the matriarchal line. This fact, coupled with the dominant position of the woman in the household activities, assured her primacy in the family.

This matriarchal communistic system was destroyed by males once they began to produce surplus goods that contributed to their status. Since they then wanted to pass their property on to offspring they knew to be theirs, the single family unit was developed. In order to further ensure their supremacy, they prevented women from working outside the household where they might acquire material possessions of their own. Hence, for Marx and Engels, " $(t)$ he enemy was defined. It was not the male sex but the institution of private property: capitalism" (p. 35). The solution was to be found in socialism, which would abolish private property and emancipate women from household concerns so that they would be able to engage in production to the same extent as men. This involved converting individual domestic work and child care themselves into public industries or services.

After presenting the socialist ideological position, Scott uses Czechoslovakia as a case study of how socialism in practice has responded to the ideological challenge. She reviews legislation designed to encourage female participation in the work force and various social programs that affected women's ability to work, such as programs for child care, centralized food preparation and laundry service, legal abortion, etc. Scott's review of the history of these legislative and social programs makes clear that, just as economics determined woman's place in primitive society in socialist theory, so economics continues to determine her fate in socialist practice. Ideological and programmatic changes have 
occurred as a function of economic and political need. After the war, when Czechoslovakia needed to mobilize fully for industrial development, a flurry of legislation and social programs encouraged women's participation in the work force. (A municipally operated organization called the Liberated Household even offered laundry and housecleaning services, and laundry could be picked up and delivered at the place of work.) Later, when an effor for greater industrial productivity led to questioning of the wage equalization program and new calls for wage differentials to increase productivity, unskilled positions largely occupied by women were cut back and the larger amounts of money needed to finance wage increases were taken from programs designed to help women workers. Similarly, when it was recognized that female employment resulted in a decline in the birth rate, legal abortions were restricted. Ideological rationales for the return of women to their homes were provided in discussions of the "natural" division of labor in the family and calls for social recognition of household work.

Scott concludes that socialism has not liberated women, for two main reasons. First, the Marxist "theory" of the "woman question" has remained undeveloped, essentially where Engels left it almost a century ago, and unable to cope with the realistic problems faced by women who work. State programs to foster equality of women therefore founder on the shoals of impracticality (it takes 3 weeks to get the laundry back and deliveries were discontinued), contradiction, and social dysfunction and are determined more by political and economic exigencies than by the real needs and condition of women. This conclusion seems amply buttressed by the data Scott presents. However, the premise that a major cause of the problem is the absence of a socialist theory that would redefine the functions of the family and traditional sex roles seems more debatable. Acceptance of this premise implies that social change occurs primarily as a consequence of ideology rather than material circumstances and reality, a premise that is clearly not supported by Scott's description of the Czechoslovak experience in the area of women's liberation. Without intellectually confronting the deviations from Marx and Engels' position on sexual equality, ideology has clearly changed as a function of economic and social need.

In other countries as well, the evidence suggests that the full-blown ideology of feminine equality follows economic liberation at least as much as it encourages it. The leaders of the women's movement in the United States, for example, have come largely from the upper middle class, and from women who have achieved a good measure of economic and professional success. The social class split within the women's movement in this country and the somewhat analogous schism between women from developed and third world countries manifested at the United Nations Conference on Women in Mexico City in 1975 illustrate the difficulties of imposing an ideology of feminine liberation on women whose material circumstances preclude their having achieved at least basic economic well-being, if not equality. 
Perhaps at this stage of development in Czechoslovakia and elsewhere in the Soviet system, the theory that is most important is already present in the basic socialist commitment to sexual equality. If practical programs that help women to achieve some economic and social independence can be developed and maintained, the more radical theory that would redefine sex roles and family organization and function might follow in time. The difficulty is that the commitment to equality tends to run up against the second and real major obstacle to the liberation of women under socialism, and everywhere else for that matter - the biological function of childbearing and its attendant traditional role obligations, that can be removed for the masses of women only by the very changes in social organization and sex-role definition for which neither the ideology nor the economic base is well developed. But there is little reason to believe that at this stage of social and economic development the more radical theory would fare any better than the simple commitment to encourage sexual equality within the context of present social forms that change slowly and incrementally. This is because most people in most countries apparently do not find acceptable the social and cultural costs entailed in the more radical theory: the weakening or dissolution of the nuclear family, drastic declines in birth rate, increasing institutional care of children, and changed standards and responsiblities for household management. The social values that support current patterns will change only very slowly, but this will undoubtedly be accelerated by technological in. novation (including the time-saving consumer goods and appliances the capitalist system has been so much better at providing), and the worid-wide threat of overpopulation, which makes declining birth rates desirable rather than nationally threatening.

These factors suggest that women's liberation will proceed most rapidly in more developed rather than in less developed countries, regardless of the politico-economic system. But before one accepts ideology as irrelevant or socialism as unsuccessful in fostering women's liberation, more societies should be examined. If economic development is indeed a key to women's liberation, the choice of Czechoslovakia as a case study may have been an unfair one to represent the socialist system, since its economic development was so retarded as a consequence of being occupied following World War II. Scott demonstrates that Czechoslovakia hasn't liberated women, and perhaps it is even warranted to generalize this conclusion to the Eastern European variety of socialism. But without comparative research on socialist and non-socialist countries, including the Scandinavian countries, Great Britain, Israel, and not least of all, China, the answer to the question posed in the title of this book is still unclear.

Ada W. Finifter

Department of Political Science Michigan State University 
The Politics of Women's Liberation. Jo Freeman. New York, David McKay Co., Inc., 1975, 268 pp. $\$ 8.95$ (hardcover), $\$ 4.95$ (paperback)

The women's liberation movement is now almost 10 years old. This remarkably insightful book pulls together a complicated decade of feminist activity, showing the scope and significance of the movement, and drawing out central issues, paradoxes, and dilemmas which have marked its development. Freeman has a gift for probing beneath the obvious, and for pursuing general theoretical questions within historical details. This book will be engaging reading for feminists (who will find new meaning in past events, and a better understanding of current problems in the inovement), for those interested in social movements (who will find new theoretical contributions, as well as a superb case study), and for those interested in the political process, especially the shaping of public policy (this book calls attention to a neglected field: the relationship of social movements to the formation of policy).

Freeman's analysis is based on impressive data. She was an activist in the New Left, and helped organize the first independent women's liberation group in the country (in Chicago), which became a nucleus of the "younger" branch of the movement. Later Freeman became a member of the National Organization of Women (NOW). From the beginning, she made it a point to watch and record, along with participating. She supplemented participant-observation with interviews with feminists around the country, and later - when the movement had had an impact - with those involved in making government policy relevant to women.

Only a feminist who had been in the thick of the movement could write with the sensitivity to details, and with the overall feel for the recent history of feminism, which characterize this analysis. At the same time, Freeman is able to stand back, to capture the distance needed for analysis and insight into the dynamics of the movement. This combination of involvement and detachment is the underlying strength of the book.

Making sense of the diversity of the movement, Freeman distinguishes two branches, the "older," including groups like NOW and the National Women's Political Caucus, and the "younger," consisting of numerous small groups engaged in a variety of activities like consciousness-raising, running women's centers, and producing feminist underground publications. The distinction is not one of ideology - Freeman argues that ideological differences have been of relatively minor importance in the history of the movement - but of origins, structure, and style. The older branch was formed by women who made contact in the early and mid.1960s through government commissions on the status of women; it is older in its earlier origins, and in the average age of the founders. The style of organization is traditionally formal, with elected officers, bylaws, and a generally top-down rather than mass-base structure. 
The younger branch was formed separately, by women who had been active in the New Left, and who eventually reacted to the male dominance of the civil rights, anti-war, and student movements. Rather than organizing from a national center, this branch has proliferated through local, largely autonomous groups which have sought to avoid formal organizational structures, and have experimented with less hierarchical, more person-oriented styles.

In detailing the history of the older and younger branches, Freeman raises several important theoretical questions. One - long neglected by those studying social movements - is the question of how movements originate. Freeman shows the importance of a preexisting, cooptable communications network (e.g., the women in contact through government commissions, or through the New Left) in providing the initial organizing core of a new social movement.

The dynamics and consequences of "structurelessness" form another theme which runs through the book and clarifies dilemmas central to the younger branch of the movement. Starting with Weber and Michels, social scientists have long theorized about the inevitability of bureaucratization, oligarchy, and conservatism when groups seeking social change obtain a base in society. Little attention has been paid, however, to the fate of groups which have deliberately sought to avoid structure, as the younger branch of the movement has done out of distaste for hierarchies which have traditionally relegated women to subordina. tion, and as an outgrowth of the New Left ideology of "participatory democracy."

Contrary to the Weber/Michels model, "in this movement it is the more organized, bureaucratic older branch that has so far shown less transformation in a conservative direction over time, and the lesser organized one that shows more" (p. 10). Freeman is at her most insightful in sorting out this paradox. The small groups of the younger. branch have emphasized participation by everyone, sharing of tasks, and a conscious lack of formal structure and leaders. While this style has furthered personal change, learning of skills, flexibility, and innovation, it has resulted in serious problems. In the absence of formal organization, covert power structures based on exclusive friendship networks, and nonaccountable leaders, chosen more by the media than the movement, came to dominate. Structurelessness also hampered political effectiveness: energy was focused on maintaining participatory groups, and a high degree of local autonomy made it difficult to coordinate nationai activity.

Alongside a fine-grained analysis of the inner workings of each branch, Freeman sets out an overall picture of the movement, noting the interrelationships of the older and younger branches (which, in the last 2 years, have begun to merge). The younger branch has been more ideologically innovative, raising new issues (e.g.. lesbianism), and exerting a radical pull on the older branch "what began as a debate within the radical underground feminist media eventually emerges as a NOW resolution" (p. 99). Freeman argues that this ideolo- 
gical pull from the younger branch is a major reason groups like NOW have moved in a more radical rather than conservative direction (the conservatism of the younger branch has been structural - tied to the emergence of tight, friendship-based oligarchies - and not ideological).

On the other hand, groups like NOW have been more politically effective than the dispersed, more autonomous groups of the younger branch; it is the older branch which has launched national campaigns on issues like abortion and the Equal Rights Amendment, and had an impact on government policy.

The relation of the women's liberation movement to the making of public policy is central to Freeman's analysis (the book is based on her Ph.D. dissertation in political science). With a sharp eye for the context and impact of feminism, she documents the way in which the women's movement has influenced policy makers (when the movement emerged in 1966 and 1967, there was no national policy on the status of women).

Over time, and largely as a result of the women's movement, a new policy system on women's rights has emerged, consisting of a loosely structured network of people concerned with feminist issues and located in various government agencies, labor unions, educational institutions, media, and feminist organizations. Freeman traces the development of several policies - e.g., the Equal Pay Act of 1963, Title VII of the 1964 Civil Rights Act, and the use of federal contract compliance to further sexual equality in higher education - to document the emergence and workings of the new policy system.

Her conclusions suggest both the achievements and obstacles confronted by the women's movement: compared with the struggle of the black civil rights movement, feminists have had more rapid govermment response, in part because the civil rights movement broke the ground. But policies against sex discrimination fall far short of effective implementation, and the emergence of a backlash, e.g., groups organized against the ERA, suggests further difficulties for the future of the feminist movement.

Freeman's focus on public policy keeps her concept of "the political" very close to actual achievements, and concrete issues and campaigns. This makes for a tangible sort of description and analysis, but I had a sense that something is missing, that Freeman has settled on an overly narrow slice of the politics of women's liberation.

This limitation is partly the result of an emphasis on structure rather than ideology. For example, Freeman describes the younger branch mainly in terms of its effort to be "structureless," an effort with unintended conservative consequences. When radicals have, on principle, refused to participate in traditional political activity, such as pushing for legislation, the result has often been an inability to act, or else a turning to service projects, like abortion counseling, which have the ironic impact of maintaining the status quo.

This point is well taken, but more attention is needed to "the principle" behind this turn of events. What about the radical analysis of the roots of 
inequality, which has emerged among some feminists? Is full sexual equality a possibility under existing political, economic, and family structures? In what ways is sexism amenable to policy solutions, and what are the limitations of the policy approach to ending the subordination of women? Freeman has chosen to focus on the relationship of the movement to public policy, but the inherent limitations of public policy (within the existing political, economic, and social system) also seem relevant.

In spite of this limitation, Freeman has provided an exceptionally comprehensive and insightful study of the women's liberation movement. The analysis has a lasting quality which contributes to our basic understanding of social movements and social change. At the same time, it will be of great interest to feminists seeking to understand a shared past and present, and to reach more effectively into the future.

Barrie Thome Michigan State University

Careers and Contingencies. Shirley S. Angrist and Elizabeth M. Almquist. New York, Dunellen, University Press of Cambridge, Mass. series, 1975, 269 pp., $\$ 15.00$

This small volume reports results from a longitudinal study of women during the college years. The authors limit their claims: "The data feature attitudes and intentions rather than actual career choice. We intend to survey the study class to ascertain their life styles as adults after college and to determine what choices they made in the realms of education, work and family. Unfortunately, the follow-up is still in the future" (p. 189).

The idea of an interim report is a sound one. The development of an occupational intent during college is a problem of significant interest in itself. aside from all the exigencies. complications. and misstarts that may change it or distort its realization after college. And the data amassed during a 4-year longitudinal study present a formidable enough challenge to our techniques of data management and reduction and our capacity to grasp and comprehend meaning. By organizing and conceptualizing at the halfway point, one can hope to reduce the task and refine the analyses of that future data wave which will tell us how the story comes out in real (i.e., adult) life.

The book's strength lies in its intellectual insights. In particular. I found the authors' discussion of the contingent character of women's vocational orientation unusually cogent and useful. Theories of vocation have been formulated by males and carry the clear mark of a male orientation: women almost never conceive work choice outside the frame of decisions about marriage, parent- 
hood, friendship, and community. The authors use this discrepancy to organize their discussion of women's development in college and as a theoretical basis for developing a Life Style Index, one of their central analytic tools for describing women's pattems of orientation in college.

Analysis is the weaker aspect of the monograph. One sociologist I know said of the book, "I was disappointed that there were so few numbers." Now, I am by no means addicted to numbers. Nor do I object to simple analytic structures. But for a study that collected an hour's worth of questionnaire information four times and a lengthy interview as well, the use of data in this monograph is slight indeed. After carefully constructing the Life Style Index and segregating five patterns of career commitment [careerists, noncareerists, converts, defectors, and shifters], the authors have the reader primed for an extensive and illuminating analysis of how women come to these paths and what distinguishes the attitudes and behavior of each group. Instead, they present case descriptions of each style and abruptly move on to another analysis.

Their longitudinal data presumably would allow them - with the use of cross-lag correlation and similar techniques - to make causal inferences about the interaction between, say, selfesteem and vocational aspiration or heterosexual status and vocational aspiration. The analysis they present clearly reveals different styles of vocational development, and one wishes for more extensive exploration of what would seem to be a very rich data base.

I use tentative phrasing because I rely here on speculation. Nowhere in the monograph are we presented with copies of the questionnaires or the interview schedule. We know that they collected data about "courses, major, school, dating, ... peers and teachers" and future plans for education, work, marriage, and children, and we are introduced to a number of questionnaire items in the text. But nowhere do we get an overall view of the information gathered.

This brings me to one other criticism: the book is edited as badly as any I have ever seen. Errors and typos abound. We are told that bracketed response altematives in a table of items indicate career salience but find no brackets. Some of this disheveled editing can be laid at the door of the publisher (which should do better for the price of the book). But the authors had galleys and could surely have caught more of the errors than they did.

The book is nonetheless valuable. It contains many useful and provocative discussions, points to topics (e.g., modeling) which need a fresh research approach if they are to help us to understand career choice and planning in women, and tantalizes us for the next report from this very rich study. Jessie Bernard's foreword is an excellent statement of critical problems in the field.

Elizabeth Douvan University of Michigan 